11. "Temporary hygienic norms of the content of chemical and biological contaminants Nature in Biologically Active Additives "ГН 4.4.8.073-2001: Resolution Chief Sanitary Doctor of Ukraine dated April 20, 2001 [Text]. - Official bulletin Of Ukraine. - 2001. - Vol. 131. - P. 316-332.

12. Chudeshov, V. I. Technology of medicines for industrial production [Text] / V. I. Chudeshov, L. M. Khokhlova, O. O. Lyapunov et. al.; V. I. Chueshov (Ed.). - Kharkiv: Publishing NUPh "Golden pages", 2003. - 720 p.

13. Shteyngardt, M. V. Solid dosage forms [Text]: Coll. sci. paper. / M. V. Steinhardt, N. A. Kazarinov // Technology and standardization of drugs. - Kharkiv: LLC «Reereg», 1996. - P. 539-605.

14. Savelieva, E. V. Determination of effect of Ballota nigra extract on the state of lipid peroxidation and rats' antioxidant system under chronic immobilization stress [Text] / E. V. Savelieva, I. N. Vladymyrova, T. S. Tishakova // Der Pharmacia Lettre. 2016. - Vol. 8, Issue 5. - P. 227-230.

Дата надходження рукопису 27.10.2017

Elena Savelieva, Department of Medical and Bioorganic Chemistry, Kharkiv National Medical University, Nauky ave., 4, Kharkiv, Ukraine, 61022

E-mail: elena_s12@ukr.net

Inna Vladymyrova, Doctor of Pharmaceutical Sciences, Associate Professor, Department of Pharmacognosy National University of Pharmacy, Pushkinska str., 53, Kharkiv, Ukraine, 61002

E-mail: inna.vladimirova2015@gmail.com

Tatyana Tishakova, PhD, Department of Medical and Bioorganic Chemistry, Kharkiv National Medical University, Nauky ave., 4, Kharkiv, Ukraine, 61022

E-mail: ttishakova@ukr.net

Olga Levashova, PhD, Department of Medical and Bioorganic Chemistry, Kharkiv National Medical University Nauky ave., 4, Kharkiv, Ukraine, 61022

E-mail: olga.jdan78@gmail.com

УДК: 615.454.124.014.23 : 615.28

DOI: $10.15587 / 2519-4852.2017 .119890$

\title{
SUBSTANTIATION OF THE COMPOSITION OF SURFACE-ACTIVE SUBSTANCES IN DEVELOPMENT OF A CREAM WITH SILVER CITRATE
}

\author{
(C) Z. Polova, I. Gladukh, H. Kukhtenko
}

Фармацевтичним емульсіям нині приділяється все більша увага, оскільки вони нашли широке застосування в медичній практииі. Це стало можливим завдяки якісно новому рівню наукових досліджень та досягнень в області створення емульсійних систем, а також розширенню асортименту допоміжнх речовин та використанню нового сучасного обладнання. Емульсї являють собою гетерогенні дисперсні системи, щзо потенційно нестабільні. Тому питання стабілізації емульсійних систем є головним в технологї емульсій.

Мета. Вивчення структурно-механічних властивостей концентрованих емульсійних систем в залежності від сумарної концентрачї ПАР та дослідження колоїдної та термічної стабільності зразків для обгрунтування складу поверхнево-активних речовин при розробиі крему з срібла ицитратом.

Методи. Фармако-технологічні методи досліджень проводили згідно з вимогами Державної Фармакопеї України.

Результати дослідження. Досліджено колоїдну та термічну стабільність зразків крему емульсійного з срібла цитратом, за якими встановлено, що використання емульгаторів в концентрації $4 \%$ та $6 \%$ не забезпечує фізичної стабільності. Виконано дисперсний аналіз гетерогенних систем, за якими встановлено, щчо зразки із використанням комбінації емульгаторів є однорідними за розміром частинок масляної фази, які не перевищують 10 мкм. Досліджено поведінку зразків емульсійного крему з срібла иитратом під час та після механічної деструкиії, результати яких гарантують стабільність системи під впливом механічної обробки в процесі промислового виробниџтва та використання.

Висновки. В результаті експерименту обтрунтовано використання для стабілізації емульсійної системи з срібла ичитратом комбінацію поверхнево-активних речовин: емульгатор № 1 та цетостеариловий спирту у кількості 8-10\%

Ключові слова: емульсійна система, поверхнево-активні речовини, крем, цитрат срібла, стабільність 


\section{Introduction}

Soft medicinal forms are widely used, but emulsion creams, which are homogeneous and consisting of at least two mutually unmixed or partially mixed liquids, are the most widespread. The problem of emulsion systems stability is important technological issue [1].

To increase aggregate stability, stabilizersemulsifiers and stabilizers-thickeners are introduced into emulsions; they reduce the interfacial surface tension between two phases, form strong protective coatings on the particles surface, and increase viscosity of the dispersion medium. Significant stabilization preventing flocculation, coalescence and kinetic instability, can be achieved if structural and mechanical barrier, characterized by high structural viscosity parameters, is formed in the dispersion medium volume and on the verge of phase separation. Introduction of surface-active substances (surfactants) allows accelerate drugs resorption; they act as plasticizers, improving the structural and mechanical properties of disperse systems [2].

When selecting emulsifiers for pharmaceutical emulsions, it is recommended to figure on their stabilization mechanism, toxicity, $\mathrm{pH}$, and chemical compatibility with active pharmaceutical ingredients (API). To stabilize emulsions, emulsifiers are used in a wide concentrations range from 0.1 to $25 \%$ [3]. Therefore, it is important to choose the optimal composition of emulsifiers in cream composition.

2. Formulation of the problem in a general way, the relevance of the theme and its connection with important scientific and practical issues

When designing the composition and technology of any emulsion it is necessary to consider API's properties, method for obtaining, rheological, electrical and dielectric properties, as well as stability during storage. The problem of physical stability is the main in emulsion production technology area.

Surfactant is the essential component of disperse systems. It's about compounds that are not distributed homogeneously in solution, and due to their amphiphilic nature, they accumulate (adsorbed) on the verge of phase separation. A decrease in the interfacial tension due to adsorption monolayers formation is caused by the adsorption on the verge of phase separation. An indispensable condition for such interphase activity manifestation (concentration on the verge of phase) is the presence of lipophilic and hydrophilic functional groups in surfactant molecule. It can be considered that all emulsifiers are surface-active substances. It is emulsifiers that represent compounds that take a crucial part in formation and stabilization of emulsion $[4,5]$. Therefore, it is important to select the type and concentration of surfactants that would provide a stable emulsion.

\section{Analysis of recent studies and publications in which a solution of the problem and which draws on the author}

Trends in development of emulsions for skin application are determined along with the other, consumer characteristics, and environmental aspects are increasingly considered. Thus, currently there is a need for particularly compatible emulsifiers, which should be obtained at the same time on the basis of raw materials from renewable resources. Besides, the absence of unwanted concomitant substances that may occur during the emulsifiers obtaining process expected $[6,7]$.

Peptides are widely studied as emulsifiers due to their biocompatibility, universality and stabilizing ability. However, costs and mass production remain problematic for wider use of these emulsifiers. There is evidence about the potential use of silk fibroin nanofibers as emulsifiers in medicines and cosmetics. Compared to peptide emulsifiers, nanofibers have several advantages: besides the improved stabilizing ability, silk nanofibers provide additional stability to emulsions formed at high salt concentration and low $\mathrm{pH}[8]$.

The authors [9] describe that some of the highly dispersed solid particles, when added to a mixture of water with non-polar solvents, are able to stabilize emulsions formed even without surfactant. The so-called Pickering emulsions are widely used in the cosmetics industry. Different particles were used to stabilize emulsions, such as, for example, colloidal silicon dioxide, hydrophobic Aerosil, polystyrene microspheres, carbon nanotubes, zinc oxide, clay particles, aluminum hydroxide, magnetite, and others.

The source [10] presents the data about the basic principles of stabilization of emulsions by polymeric surfactants. Particular attention is paid to polymeric surfactants suitable for oil-in-water $(\mathrm{o} / \mathrm{w})$ and water-in-oil (w/o) emulsions, namely hydrophobically modified inulin.

Emulsifiers used for development of pharmaceutical and cosmetic emulsions, as surfactants, are mostly amphiphilic. The lipophilic residues are aliphatic or aromatic. Hydrophilic groups are formed by polar structural elements which can be electrically charged or uncharged; therefore, on the assumption of the hydrophilic functional group, it is possible to divide into ionic and nonionic emulsifiers $[11,12]$.

Properties of emulsions also depend on composition and concentration of the emulsifiers. It is necessary to select the emulsifying mixture composition according to the additivity rule in determining the "required" hydrophilic-lipophilic balance (HLB) for oil phase and guided by the theoretical data about the HLB system application, whereby it is recommended to use two surfactants, one of which is characterized by high HLB value, and the second - by low one [13].

\section{Allocation of unsolved parts of the general} problem, which is dedicated to the article

The use of surfactants, which due to their diffusive structure are adsorbed on the interphase surface and thereby reduce the surface tension, is one of the ways to stabilize emulsions. To stabilize the oil/water emulsion system, which is used for the present research as a basis for the pharmaceutical development of a cream containing a silver citrate solution, the surfactants such as cetyl stearyl alcohol, glyceryl monostearate, polysorbate-80, and emulsifier № 1 were studied. On the basis of the previous studies $[14,15]$, the use of the surfactants combination: emulsifier № 1 and cetyl stearyl alcohol in the ratio of $1: 1$, and emulsifier № 1 singly was grounded. The given work is a continuation of the experimental 
studies and is devoted to the research of the emulsifiers total concentration influence on the physical, structural and mechanical, and disperse properties of oil/water emulsions.

\section{Formulation of goals (tasks) of Article}

The aim of the research is to study the structural and mechanical properties of concentrated emulsion systems, depending on the surfactants total concentration, and the study of colloidal and thermal stability of the samples for substantiation of the surfactants composition in the development of the cream with silver citrate.

6. Statement of the basic material of the study (methods and objects) with the justification of the results

The objects of research were concentrated $21 \%$ emulsion systems. The oil phase included vaseline oil, isopropyl myristate, isopropyl palmitate, octyldodecanol by $5 \%$ each and $1 \%$ of dimethicone. Purified water was used as dispersion environment. Two series of the samples were prepared: the first one containing nothing but emulsifier № 1, and the second one containing the mixture of emulsifier № 1 and cetyl stearyl alcohol in the ratio of $1: 1$. In the samples, the total concentration of emulsifiers was $10 \%, 8 \%, 6 \%$, and $4 \%$ at calculated ratio of these substances. The samples composition is shown in Table. 1.

The samples were prepared using high/high temperature method, in which the oil and water phases were heated separately to a temperature of $70-75{ }^{\circ} \mathrm{C}$. The emulsification of the samples was carried out using Rolutron ${ }$ Sutemem RT 2500 (Kinematis AG, Switzerland) homogenizer at a speed of $5000 \mathrm{rpm}$. After decreasing the temperature of the sample to $50-55{ }^{\circ} \mathrm{C}$, silver solution and panthenol were added. The samples were left for a day to structure the disperse system and then they were used for rheological research.

Table 1

The samples composition

\begin{tabular}{|c|c|c|c|c|}
\hline \multirow[t]{2}{*}{ Substances } & \multicolumn{4}{|c|}{ Composition, \% / The sample series number } \\
\hline & 1 & 2 & 3 & 4 \\
\hline \multicolumn{5}{|c|}{ Active pharmaceutical ingredient } \\
\hline \multicolumn{5}{|l|}{ Silver citrate solution } \\
\hline \multicolumn{5}{|l|}{ Dexpanthenol } \\
\hline \multicolumn{5}{|c|}{ Disperse phase } \\
\hline Vaseline oil & \multicolumn{4}{|c|}{5} \\
\hline Isopropyl myristate & \multicolumn{4}{|c|}{5} \\
\hline Isopropyl palmitate & \multicolumn{4}{|c|}{5} \\
\hline Octyldodecanol & \multicolumn{4}{|c|}{5} \\
\hline Dimethicone & \multicolumn{4}{|c|}{1} \\
\hline \multicolumn{5}{|c|}{ Surfactants composition (SERIES 1) } \\
\hline Emulsifier №1 & 10 & 8 & 6 & 4 \\
\hline \multicolumn{5}{|c|}{ Surfactants composition (SERIES 2) } \\
\hline Emulsifier №1 & 5 & 4 & 3 & 2 \\
\hline Cetyl stearyl alcohol & 5 & 4 & 3 & 2 \\
\hline \multicolumn{5}{|c|}{ Disperse environment } \\
\hline Purified water & & & & \\
\hline
\end{tabular}

Determination of rheological or structural and mechanical properties of the samples. The study was carried out by Rheolab QC Rheometer (Anton Paar, Austria) using C-CC27/SS coaxial-cylinder system. The device meets ISO 3219 the requirements. The rheological curve measurements were carried out in three stages:

a) linear increase of the shear rate from $0.1 \mathrm{sec}^{-1}$ to $350 \mathrm{sec}^{-1}$ with 115 measurement points and the measuring point duration of $1 \mathrm{sec}$;

b) constant sheer at the shear rate of $150 \mathrm{sec}^{-1}$, one measurement point with a duration of $1 \mathrm{sec}$;

c) linear decrease of the shear rate from $350 \mathrm{sec}^{-1}$ to $0.1 \mathrm{sec}^{-1}$ with 115 measurement points and the measuring point duration of $1 \mathrm{sec}$.

The study of thixotropic properties (under "destruction-restoration" conditions) was carried out in three stages:

a) constant sheer at the rate of $1 \mathrm{sec}^{-1}, 5$ measurement points, duration of the point measurement $5 \mathrm{sec}$;

b) constant sheer at the rate of $150 \mathrm{sec}^{-1}, 50$ measurement points, duration of the point measurement $1 \mathrm{sec}$; c) constant sheer at the rate of $1 \mathrm{sec}^{-1}, 250$ measurement points, duration of the point measurement $1 \mathrm{sec}$. was $25^{\circ} \mathrm{C}$

The temperature of rheological properties study

Determination of the samples colloidal stability. For the test, laboratory centrifuge with a set of test tubes, mercury thermometer with measurement scales from 0 to $100{ }^{\circ} \mathrm{C}$ and value of division of $1{ }^{\circ} \mathrm{C}$, as well as stopwatch and water bath, were used. The test tubes were filled to 2/3 of the volume (approximately $9 \mathrm{~g}$ ) by the test samples (in result, masses of the test tubes with the preparations did not differ by more than $0.02 \mathrm{~g}$ ) and weighed with accuracy up to $0.01 \mathrm{~g}$. Then, the test tubes were placed into a water bath at a temperature of $42.5 \pm 2.5^{\circ} \mathrm{C}$ for 20 minutes, after that they were wiped to dryness from the outside and placed in the centrifuge. The samples were centrifuged for 5 minutes at a speed of 6000 $\mathrm{rpm}$ (the relative centrifugation force was about $5000 \mathrm{~g}$ ).

The samples were considered to be stable if in the test tubes no stratification was observed after centrifugation. If stratification or sedimentation of the sample were 
found at least in one sample, the analysis was carried out again. If a retest showed at least one test tube with stratification, the sample was considered to be unstable.

Determination of thermal stability of samples. 5-6 glass tubes with a diameter of $15 \mathrm{~mm}$ and a height of $150 \mathrm{~mm}$ were used for research. The test tubes were filled by $8-10 \mathrm{ml}$ of the test samples and placed into a TC-80M-2 thermostat with a temperature of $42.5 \pm 2.5^{\circ} \mathrm{C}$ for 7 days. After that, the samples were transferred for 7 days to refrigerator with a temperature of $6 \pm 2{ }^{\circ} \mathrm{C}$ and then they were kept at a room temperature for 3 days. Stability was determined visually: if no stratification observed in any test tube, the sample was considered to be stable.

Microscopy research method. To study the microscopy of the emulsions, a Lumam P1 microscope, equipped with a digital DMC 300 digital camera, and ScopePhoto software, were used. A small drop of emulsion, which was taken with a glass rod from the middle part of the prepared samples, was placed on the slide glass. Then, the drop of emulsion was covered with a cover glass. Then the cover glass was gently pressed with a rod until a homogeneous thin layer, transparent when viewed with the naked eye, is obtained. The slide glass with the prepared sample was placed on the microscope's stage table. To examine the samples, a lens with a magnification of 20x and an 1.6 intermediate magnification was used. The samples were viewed under a halogen lamp. Microscopy pictures were obtained using the Scope Photo software. Automatic white balance and brightness settings were used. Comparison scale $(50 \mu \mathrm{m})$ was applied on the pictures using a calibrated system.

The evaluation of the quality of emulsions as a basis of a soft medicinal form was carried out by a set of such indicators as stability, homogeneity of disperse phase particles and consistency [16]. The consistency or visco-elastic properties of the studied samples were evaluated according the rheological studies results shown in Fig. 1-4 and Table 2. As it is shown, all samples are characterized by visco-elastic properties; the greater their severity, the higher surfactants concentration. All samples have a pseudoplastic flow type, the flow of which begins after reaching the marginal shear strain (flow limits), which is neces- sary to begin the system flow (Table 2). The shear stress value indicates how easy the cream will be extruded from the tube and the adhesion on skin surface, or on the contrary, indicates the spontaneous leak from the tube and spread over the surface. The segment on the axis ordinate from 0 to the marginal sheer stress $\left(\tau_{0}, \mathrm{~Pa}\right)$ points to the elastic properties of the disperse system, the segment of ordinates above the marginal sheer stress - to the plastic properties.

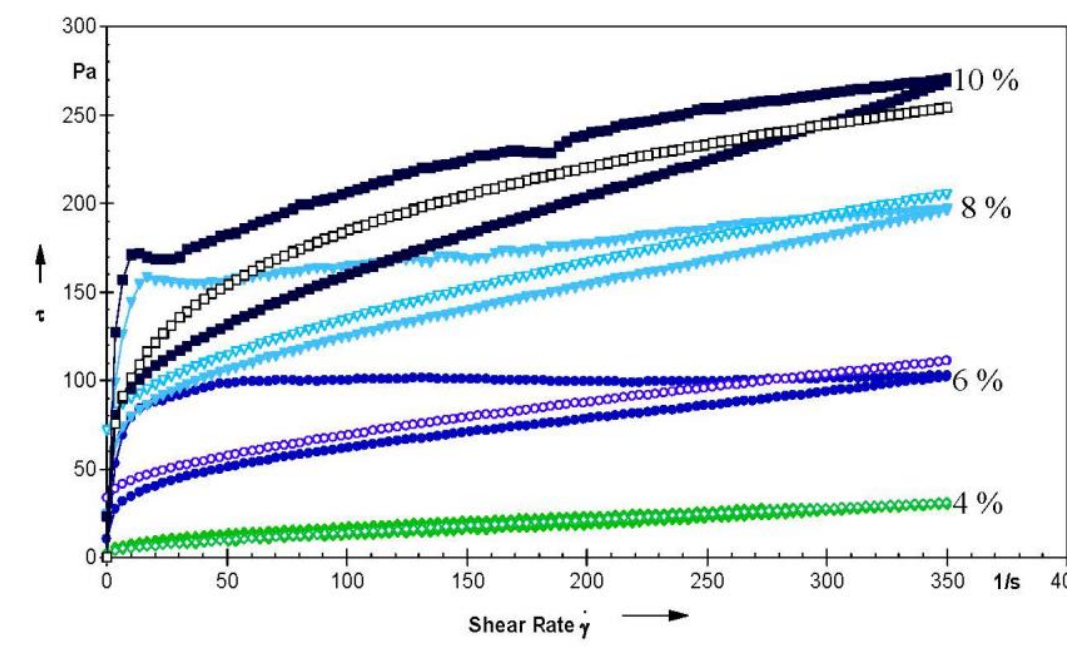

Fig. 1. The samples with emulsifier № 1 (SERIES 1) shear curves

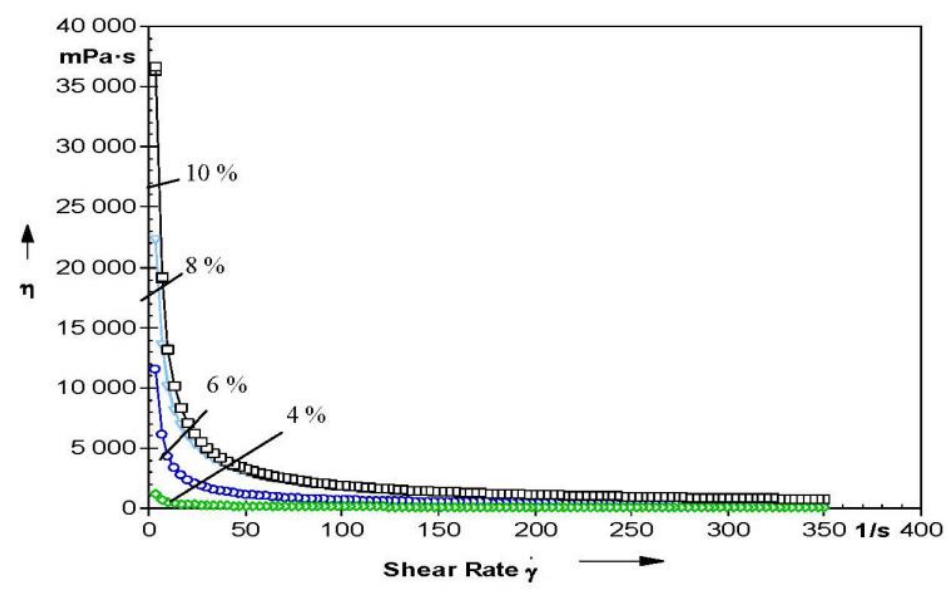

Fig. 2. The samples with emulsifier №1 (SERIES 1) viscosity curves

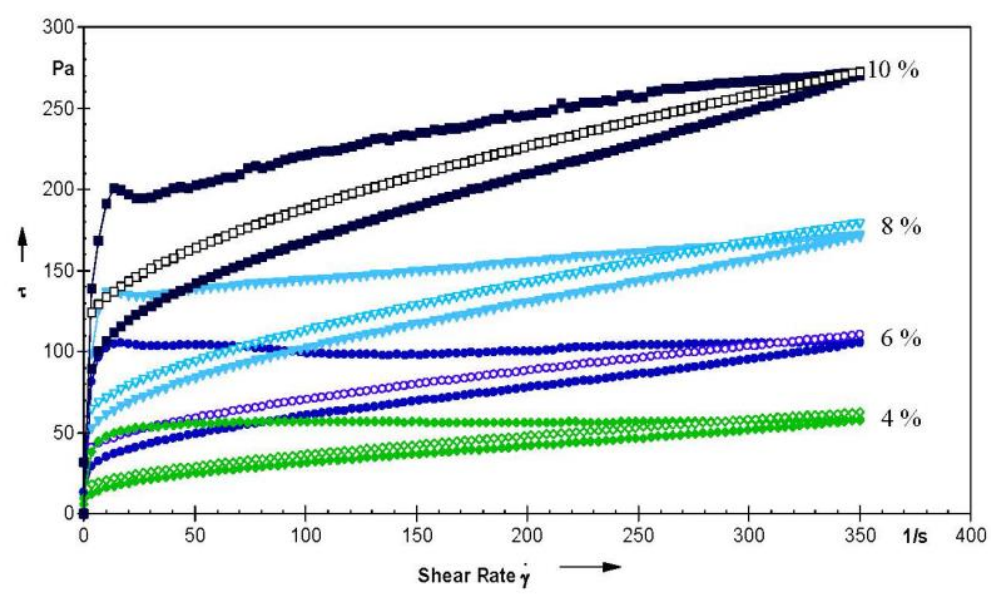

Fig. 3. The samples with combination of emulsifier № 1 and cetyl stearyl alcohol (SERIES 2) shear curves 
All samples have thixotropic properties, since the ascending curve describing the sample behavior in increasing the shear rate direction, and the downward curve that describes the sample behavior in the opposite direction, form a hysteresis loop.

Fig. 2 and 4 show the viscosity curves, where it is evident that the structural viscosity of the samples de- creases with deformation effort increase, which in turn indicates the pseudoplasticity of the disperse systems.

The stability properties of the studied emulsions have a significant influence on the disperse systems stability and are provided by surfactants [17]. The stability of the studied samples was analyzed by colloidal and thermal stability tests. The results are given in Table. 3

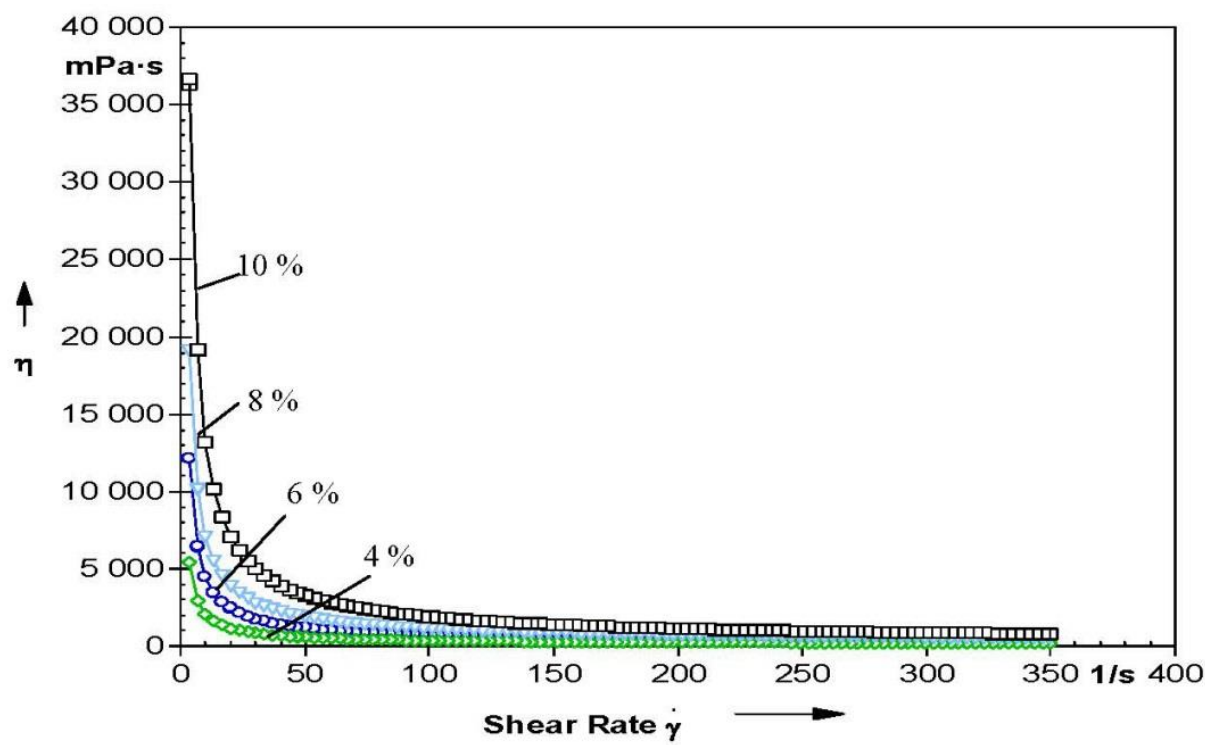

Fig. 4. The samples with combination of emulsifier № 1 and cetyl stearyl alcohol (SERIES 2) viscosity curves

Marginal shear stress (shear limit) by Casson

\begin{tabular}{|c|c|c|c|}
\hline $\begin{array}{c}\text { Samples } \\
\text { SERIES 1 }\end{array}$ & $\boldsymbol{\tau}_{\mathbf{0}}, \mathbf{P a}$ & $\begin{array}{c}\text { Samples } \\
\text { SERIES 2 }\end{array}$ & $\boldsymbol{\tau}_{\mathbf{0}}$, Pa \\
\hline $1(10 \%)$ & 68.30 & $1(10 \%)$ & 110.55 \\
\hline $2(8 \%)$ & 55.168 & $2(8 \%)$ & 71.75 \\
\hline $3(6 \%)$ & 35.36 & $3(6 \%)$ & 33.24 \\
\hline $4(4 \%)$ & 15.01 & $4(4 \%)$ & 2.75 \\
\hline
\end{tabular}

Note: $n=6, p \leq 0.05$ - the index deviation is reliable compared with the control

Table 3

Colloidal and thermal stability of the samples

\begin{tabular}{|c|c|c|c|c|c|}
\hline $\begin{array}{c}\text { Samples } \\
\text { SERIES 1 }\end{array}$ & $\begin{array}{c}\text { Colloidal sta- } \\
\text { bility }\end{array}$ & Thermal stability & $\begin{array}{c}\text { Samples } \\
\text { SERIES 2 }\end{array}$ & $\begin{array}{c}\text { Colloidal } \\
\text { stability }\end{array}$ & Thermal stability \\
\hline $1(10 \%)$ & + & + & $1(10 \%)$ & + & + \\
\hline $2(8 \%)$ & + & + & $2(8 \%)$ & + & + \\
\hline $3(6 \%)$ & + & - & $3(6 \%)$ & + & - \\
\hline $4(4 \%)$ & - & - & $4(4 \%)$ & - & - \\
\hline
\end{tabular}

Note: $n=6, p \leq 0.05$ - the index deviation is reliable compared with the control

As it is shown in Table 3, the use of surfactant in a concentration of $4 \%$ does not provide either colloidal stability or thermal stability of concentrated emulsion systems. The total surfactant concentration of $6 \%$ provides only colloidal stability. The use of surfactant in a concentration of $8-10 \%$ provides thermal and colloidal stability of the emulsion disperse system.

The quality of any emulsions is also determined by their dispersion, namely the size of the dispersed phase. Primarily the dispersion of emulsions characterizes the uniformity of oil components distribution, emulsion stability and viscosity. The results of the dispersion analysis are shown in Fig. 5 and 6.
As it can be seen from the pictures, the samples of the series 2 prepared by using the surfactant combination of emulsifier № 1 and cetyl stearyl alcohol have correct shape droplets of oil phase that are evenly distributed throughout the emulsion volume. The density of droplets with a total concentration of $10 \%$ and $8 \%$ is the same. In the samples, prepared by using only emulsifier № 1 there are oil phase droplets $25-50$ microns size in the emulsion volume. Thus, on the basis of rheological, microscopic studies and stability studies of oil/water emulsion systems, it is expedient to use a mixture of surfactant emulsifier № 1 and cetyl stearyl alcohol in a ratio of 1:1 at a total concentration of 8-10\% for stabilization. 
During the manufacturing process, soft drugs are under the mechanical effects (homogenization, pipeline transport, packaging on high-performance equipment, etc.), resulting in medicinal product destruction. During pharmaceutical development, one of the obligatory stages of the research is mechanical stability study. To examine the mechanical stability of the disperse system, a "destruction-recovery" test was carried out using a rotary reoviscosimeter, the test method is given above. During the experiment, the initial structural viscosity of the sample was recorded at a deformation rate of $1 \mathrm{sec}^{-1}$, then the sample was deformed using the inner cylinder for $50 \mathrm{sec}$ with a displacement rate of $150 \mathrm{sec}^{-1}(120 \mathrm{rpm})$ with the following period of structure restoration under the initial conditions .

Results of the study of mechanical stability of the samples under "destruction-recovery" conditions are shown in Fig. 7 and Table 4.

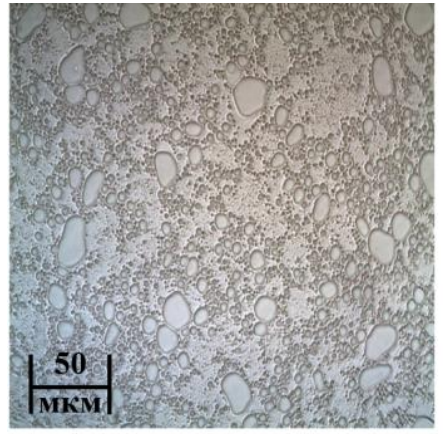

$1(10 \%)$

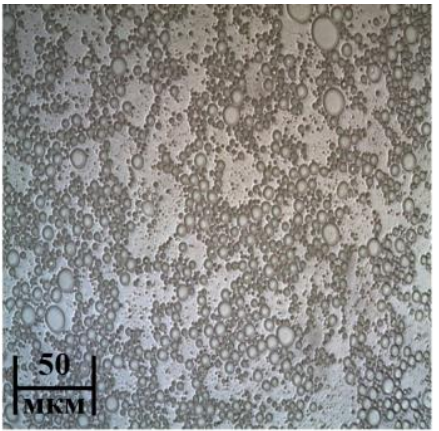

$2(8 \%)$

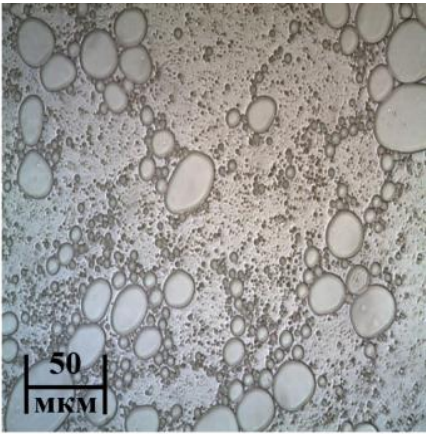

$3(6 \%)$

Fig. 5. Microscopy pictures of the samples SERIES 1

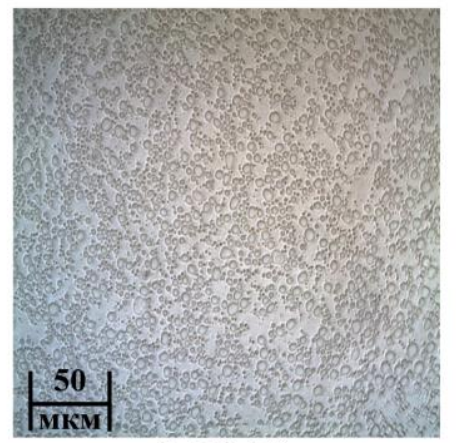

$1(10 \%)$

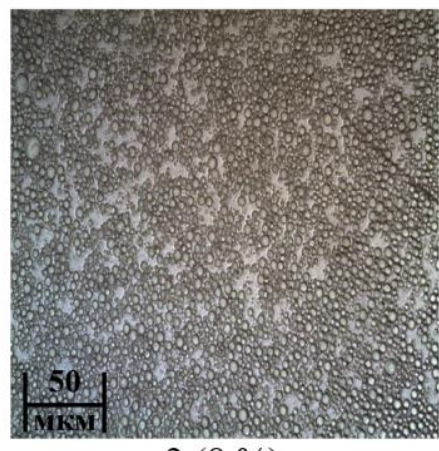

$2(8 \%)$

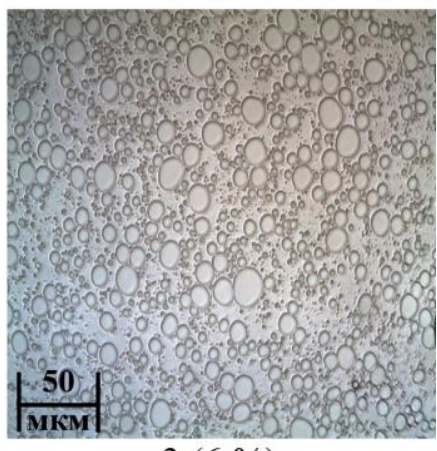

$3(6 \%)$

Fig. 6. Microscopy pictures of the samples SERIES 2

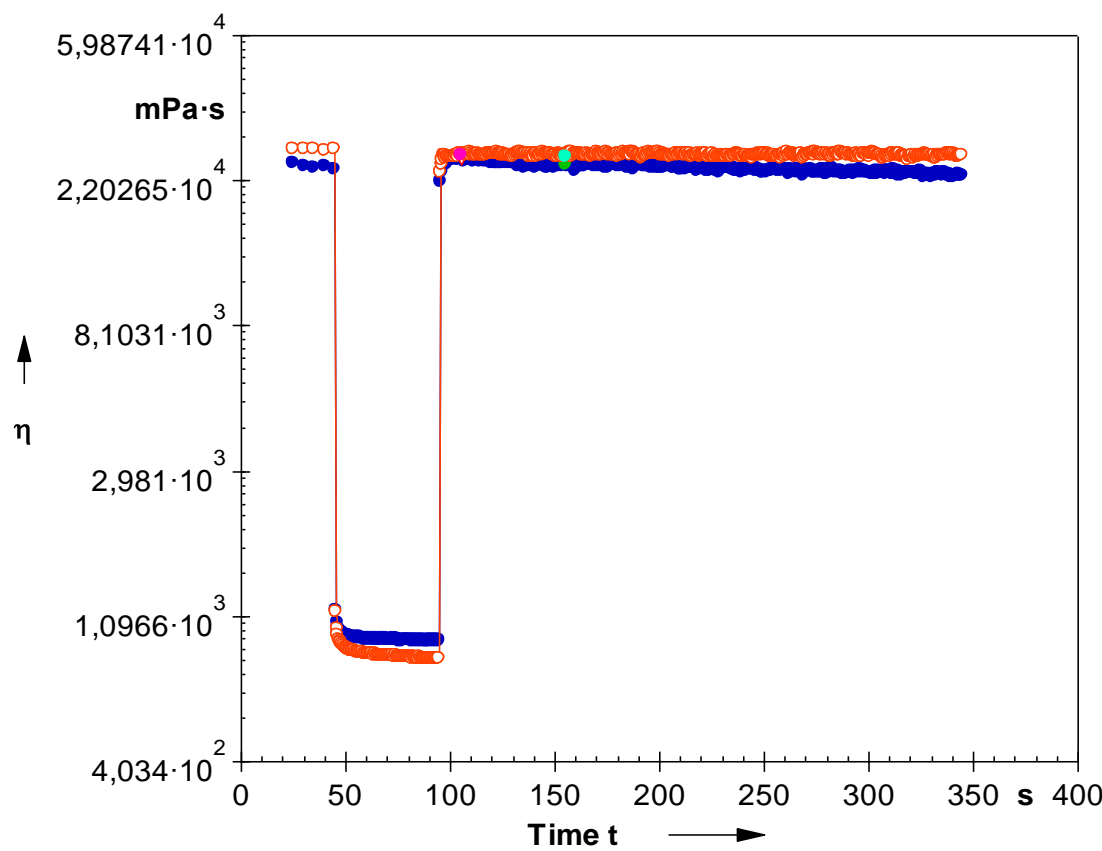

$8 \%$

CC27/S-SN29766; d=0 mm

$\rightarrow \eta$ Viscosity

$8 \%$

Delta $=108,04 \%$ after $t=10 \mathrm{~s}$

$\rightarrow \eta \quad$ Viscosity

$8 \%$

Delta $=103,12 \%$ after $t=60 \mathrm{~s}$

$\rightarrow \eta$ Viscosity

$8 \%$

Delta $=104,8 \%$

- $\eta$ Viscosity
$10 \%$

CC27/S-SN29766; d=0 mm

- $\eta$ Viscosity

$10 \%$

Delta $=96,447 \%$ after $\mathrm{t}=10 \mathrm{~s}$

$\rightarrow \eta$ Viscosity

$10 \%$

Delta $=95,15 \%$ after $\mathrm{t}=60 \mathrm{~s}$

- $\eta$ Viscosity

$10 \%$

Delta $=101,4 \%$

$\rightarrow \eta$ Viscosity

Fig. 7. Mechanical stability of the samples under "destruction-recovery" conditions 
Mechanical stability indexes

\begin{tabular}{|c|c|c|c|c|}
\hline $\begin{array}{c}\text { The surfactant } \\
\text { content in the } \\
\text { sample, \% }\end{array}$ & $\boldsymbol{\rho}_{\mathbf{0}}$, Pa·s & $\begin{array}{c}\text { Structure recovery in } \\
\mathbf{1 0} \text { seconds, \% }\end{array}$ & $\begin{array}{c}\text { Structure recovery in } \\
\mathbf{6 0} \text { seconds, \% }\end{array}$ & $\begin{array}{c}\text { Structure recovery in } \\
\mathbf{1 0 0} \text { seconds, \% }\end{array}$ \\
\hline $8 \%$ & $24700 \mathrm{~Pa} \cdot \mathrm{s}$ & $108.04 \%$ & $103.12 \%$ & $104.8 \%$ \\
\hline $10 \%$ & $27500 \mathrm{~Pa} \cdot \mathrm{s}$ & $96.45 \%$ & $95.15 \%$ & $101.4 \%$ \\
\hline
\end{tabular}

Note: $n=6, p \leq 0.05$ - the index deviation is reliable compared with the control

The data show that the samples with a total concentration of emulsifiers of $8 \%$ and $10 \%$ immediately recover their structure after mechanical influence. At the same time, the sample with a total concentration of emulsifiers of $8 \%$, at the recovery stage at low shear rates shows reoexponential properties, namely its viscosity after mechanical influence exceeds the initial one. This phenomenon needs to be studied in detail to determine the conditions under which it can be observed and its duration. In the mentioned experimental conditions, by analyzing behavior of the sample and considering the rheopexy value, we can predict that rheopexy disappears over time.

Therefore, complex physical and chemical, structural and mechanical, and microscopic studies were carried out at the stage of substantiation of the type and concentration of surfactants in the cream with silver citrate.

\section{Findings from the research and prospects of further development of this area}

1. Research of structural and mechanical properties of concentrated emulsion systems depending on the total concentration of surfactants emulsifier № 1 and cetyl stearyl alcohol in the ratio of 1:1 and only emulsifier № 1 in the second case was carried out.

2. Colloidal and thermal stability of the samples of the cream with silver citrate was studied. In result it was found that the use of the emulsifiers in concentrations of $4 \%$ and $6 \%$ does not provide physical stability.

3. Dispersion analysis of the heterogenic systems was done. It was found that the samples with the use of the emulsifiers' combination were homogenous in relation to the oil phase particle size, which did not exceed $10 \mu \mathrm{m}$.

4. Behavior of the samples of the emulsion cream with silver citrate was studied during and after mechanical destruction; results prove stability of the system under the influence of mechanical processing during manufacturing process and its use.

5. The present study resulted in substantiation of the use of surfactants combination of emulsifier №1 and cetyl stearyl alcohol in concentration of 8-10\% for stabilization of the emulsion system.

\section{Література}

1. Vasconcelos, T. Measuring the emulsification dynamics and stability of self-emulsifying drug delivery systems [Text] / T. Vasconcelos, S. Marques, B. Sarmento // European Journal of Pharmaceutics and Biopharmaceutics. - 2017. - Vol. 123. - P. 1 8. doi: 10.1016/j.ejpb.2017.11.003

2. Zafeiri, I. Fabrication, characterisation and stability of oil-in-water emulsions stabilised by solid lipid particles: the role of particle characteristics and emulsion microstructure upon Pickering functionality [Text] / I. Zafeiri, P. Smith, I. T. Norton, F. Spyropoulos // Food \& Function. - 2017. - Vol. 8, Issue 7. - P. 2583-2591. doi: 10.1039/c7fo00559h

3. Chuieshov, V. I. Tekhnolohiia likiv promyslovoho vyrobnytstva. P. 2 [Text]: pidruchnyk / V. I. Chuieshov, Ye. V. Hladukh, I. V. Saiko et. al. - Kharkiv: NFaU: Oryhinal, 2013. - 638 p.

4. Kutts, G. Kosmeticheskie kremy i emul'sii: Sostav. Poluchenie. Metody ispytaniy [Text] / G. Kutts, S. Friss, S. Khenning et. al. - Moscow: Klavel, 2004. - 272 p.

5. Cosmetic science and technology: Theoretical principles and applications [Text] / K. Sakamoto, R. Lochhead, H. Maibach, Y. Yamashita (Eds.). - Amsterdam: Elsevier, 2017. - 854 p.

6. Poverkhnostno-aktivnye veshhestva i kompozitsii [Text] / M. Yu. Pletnev (Ed.). - Moscow: OOO "Firma Klavel'", 2002. $-768 \mathrm{p}$.

7. Dermatologic, cosmeceutic and cosmetic development [Text] / Y. Walters, M. Roberts (Eds.). - Boca Raton: CRC Press, 2007. -648 p. doi: $10.3109 / 9780849375903$

8. Cheng, Q. Silk nanofibers as robust and versatile emulsifiers [Text] / Q. Cheng, B. Zhang, Y. He, Q. Lu, D. L. Kaplan // ACS Applied Materials \& Interfaces. - 2017. - Vol. 9, Issue 41. - P. 35693-35700. doi: 10.1021/acsami.7b13460

9. Yang, Y. An overview of Pickering emulsions: solid-particle materials, classification, morphology, and applications [Text] / Y. Yang, Z. Fang, X. Chen, W. Zhang, Y. Xie, Y. Chen et. al. // Frontiers in Pharmacology. - 2017. - Vol. 8. - P. 287. doi: 10.3389/fphar.2017.00287

10. Tadros, T. Principles of emulsion stabilization with special reference to polymeric surfactants [Text] / T. Tadros // Journal of Cosmetic Science. - 2006. - Vol. 57. - P. 153-169.

11. Aidarova, S. Polyelectrolyte/surfactant mixtures in the bulk and at water/oil interfaces [Text] / S. Aidarova, A. Sharipova, J. Kragel, R. Miller // Advances in Colloid and Interface Science. - 2014. - Vol. 205. - P. 87-93. doi: 10.1016/j.cis.2013.10.007

12. Pertsev, I. M. Dopomizhni rechovyny v tekhnolohii likiv: vplyv na tekhnolohichni, spozhyvchi, ekonomichni kharakterystyky i terapevtychnu efektyvnist [Text]: navch. pos. / I. M. Pertsev, D. I. Dmytriievskyi, V. D. Rybachuk et. al.; Pertsev, I. M. (Ed.). - Kharkiv: Zoloti storinky, 2010. $-600 \mathrm{p}$.

13. Kukhtenko, H. Influence of excipients on the structural and mechanical properties of semisolid dosage forms [Text] / H. Kukhtenko, I. Gladukh, O. Kukhtenko, D. Soldatov // Asian Journal of Pharmaceutics. - 2017. - Vol. 11, Issue 3. - P. $575-578$. doi: 10.22377/ajp.v11i03.1462

14. Polova, Zh. N. Obosnovanie sostava krema antimikrobnogo deystviya na osnovanii reologicheskikh issledovaniy [Text] / Zh. N. Polova // Respublikanskiy nauchnyy zhurnal «VESTNIK» Yuzhno-Kazakhstanskoy gosudarstvennoy farmatsevticheskoy akademii. - 2017. - Issue 1 (78). - P. 140-144. 
15. Polova, Zh. N. Determination of the stability of veterinary cream containing silver citrate [Text] / Zh. N. Polova // ScienceRise: Pharmaceutical Science. - 2017. - Vol. 4, Issue 8. - P. 21-26. doi: 10.15587/2519-4852.2017.108947

16. Estanqueiro, M. Comparison between sensory and instrumental characterization of topical formulations: impact of thickening agents [Text] / M. Estanqueiro, M. H. Amaral, J. M. Sousa Lobo // International Journal of Cosmetic Science. - 2016. Vol. 38, Issue 4. - P. 389-398. doi: 10.1111/ics.12302

17. Calixto, L. S. Physical-Mechanical characterization of cosmetic formulations and correlation between instrumental measurements and sensorial properties [Text] / L. S. Calixto, P. M. B. G. Maia Campos // International Journal of Cosmetic Science. - 2017. - Vol. 39, Issue 5. - P. 527-534. doi: 10.1111/ics.12406

Рекомендовано до публікації д-р фарм. наук Косяченко К. Л. Дата надходження рукопису 24.10.2017

Zhanna Polova, PhD, Associate Professor, Department of Pharmaceutical and Industrial Technology of Medicines, Bohomolets National Medical University, Tarasa Shevchenka blvd., 13, Kyiv, Ukraine, 01601 E-mail: zpolova@ukr.net

Ievgenii Gladukh, Doctor of Pharmaceutical Sciences, Professor, Head of Department, Department of Industrial Pharmacy, National University of Pharmacy, Pushkinska str., 53, Kharkov, Ukraine, 61002 E-mail: promfarm.kh.ua

Halyna Kukhtenko, PhD, Associate Professor, Department of Industrial Pharmacy, National University of Pharmacy, Pushkinska str., 53, Kharkov, Ukraine, 61002

E-mail: galinakukh@gmail.com 